\title{
Pembentukan Karakter Religius Siswa Melalui Pembiasaan Aktivitas Keagamaan
}

\section{The Formation Of Religious Characters Of Students Through Religion Activities}

\author{
Rahma Nurbaiti, ${ }^{1}$ Susiati Alwy, ${ }^{2}$ Imam Taulabi \\ 1,2Institut Agama Islam Tribakti Kediri, Indonesia \\ ${ }^{3}$ Institut Agama Islam Negeri Kediri, Indonesia \\ 1rahmanurbaiti21@gmail.com; 2susiati@iai-tribakti.ac.id,3imamtaulabi@gmail.com
}

\begin{abstract}
This study aims to find out how the religious character of students developed in the Madrasah Ibtidaiyah Negeri 2 Bandar Kidul Kediri City and how the formation of character through habituation of religious activities. The type and approach of research use descriptive qualitative. Data sources were obtained through interviews with the headmaster of the madrasa, curriculum waka, religious waka, class teachers, Islamic Religious Education teachers, several student guardians, and students. The results showed that the religious character of the students developed was devotion, sincerity, honesty, politeness, help, help, love, grace, cleanliness, competition, and gratitude. Formation of religious character through the habituation of religious activities through joint prayer before and after learning, performing dhuha and dhuhur prayers, reading juz 'amma, asmaul husna, istighasah, infaq, habituation Salam, salim, greeting, smiling, polite and polite, religious extracurricular activities such as tambourines, recite the Qur'an, the commemoration of Islamic holidays. Religious character is formed through the habituation of religious activities.
\end{abstract}

Keywords: Religious Character Building, Habituation, Religious Activities.

\begin{abstract}
Abstrak
Penelitian ini bertujuan mengetahui bagaimana karakter religius siswa yang dikembangkan di Madrasah Ibtidaiyah Negeri 2 Bandar Kidul dan bagaimana pembentukan karakter melalui pembiasaan aktivitas keagamaan. Jenis dan pendekatan penelitian menggunakan kualitatif deskriptif. Sumber data diperoleh melalui wawancara dengan kepala madrasah, waka kurikulum, waka keagamaan, guru kelas, guru Pendidikan Agama Islam, beberapa wali murid dan murid. Hasil penelitian menunjukkan bahwa karakter religius siswa yang
\end{abstract}


dikembangkan yaitu ketaqwaan, keikhlasan, kejujuran, kesopanan, tolong-menolong, cinta rosul, kebersihan, kompetitif, dan rasa syukur. Pembentukan karakter religius melalui pembiasaan aktivitas keagamaan melalui doa bersama sebelum dan sesudah pembelajaran, pelaksanaan shalat dhuha dan dhuhur berjamaah, pembacaan juz 'amma, asmaul husna, istighasah, infaq, pembiasaan Salam, salim, sapa, senyum, sopan dan santun, kegiatan ekstrakulikuler keagamaan seperti rebana, Baca Tulis Qur'an, Peringatan Hari Besar Islam. Karakter religius yang terbentuk melalui pembiasaan aktivitas keagamaan.

\section{Kata Kunci: Pembentukan Karakter Religius, Pembiasaan Aktivitas Keagamaan.}

\section{Pendahuluan}

Pendidikan karakter harus ditanamkan sedini mungkin pada anak seiring dengan perkembangan ilmu pengetahuan dan teknologi. Saat ini guru tidak hanya dituntut memiliki kemampuan sesuai dengan zaman tetapi harus mampu membentuk karakter siswa. ${ }^{1}$ Dalam membentuk karakter siswa yang kuat, berakhlak, bertaqwa dan memiliki pengetahuan yang luas guna mengembangkan potensi diri serta hubungan sosial dalam menumbuhkan kecerdasan emosional siswa, pendidikan harus memperhatikan aspek sikap dan perilaku individu, tidak hanya peningkatan pengetahuan saja. ${ }^{2}$

Proses pembentukan karakter merupakan tanggungjawab semua pihak baik guru, orang tua maupun masyarakat melalui lembaga formal dilingkungan sekolah dan lembaga non formal dilingkungan keluarga dan masyarakat. Banyak orang tua

\footnotetext{
1 Muchlas Samani dan Haryanto, Konsep dan Model Pendidikan Karakter (Bandung: PT. Rosdakarya, 2013), 1-2.

2 Dharma Kesuma, Pendidikan Karakter Kajian Teori dan Praktik di Sekolah (Bandung: PT. Remaja Rosdakarya, 2011), 2. 56
}

mempercayakan pembentukan karakter anak di sekolah tetapi terkadang kurang mendapat dukungan secara pribadi ketika di rumah, hal tersebut kurang tepat karena pembentukan karakter disekolah tidak akan sempurna jika tidak adanya kerjasama dengan orang tua. Padahal dalam ilmu pendidikan keluarga merupakan lingkungan pendidikan yang pertama dan terpenting, sebab dalam lingkungan keluarga memiliki peran sangat penting dalam membentuk karakter maupun dalam perkembangan anak untuk kehidupan selanjutnya yang akan mereka jalani. ${ }^{3}$

Karakter religius merupakan karakter pertama dan utama yang harus ditanamkan kepada anak sedini mungkin yang menjadi dasar ajaran agama dalam kehidupan individu, masyarakat dan bangsa indonesia. Karakter religius bukan saja terkait dengan hubungan ubudiyah saja tetapi juga

3 M. Arif Khoiruddin, "Perkembangan Anak Ditinjau Dari Kemampuan Sosial Emosional," Jurnal Pemikiran Keislaman 29, no. 2 (24 Desember 2018): 435, https://doi.org/10.33367/tribakti.v29i2.624. Volume 2, Nomor 1, March 2020 
menyangkut hubungan antar sesama manusia. Pendidikan karakter di sekolah memiliki peranan yang sangat penting dalam menanamkan karakter dan sekolah dasar merupakan lembaga formal yang menjadi pondasi awal siswa untuk jenjang setelahnya. Upaya dalam menumbuhkan kembali pendidikan karakter dapat ditempuh dengan mengimplementasikan pendidikan karakter melalui kegiatan pembiasaan aktifitas keagamaan.

Pembiasaan merupakan hal yang sangat penting karena seseorang akan berbuat dan berperilaku menurut kebiasaannya, tanpa pembiasaan hidup seseorang akan berjalan lambat karena harus memikirkan terlebih dahulu apa yang dilakukannya. Metode pembiasaan diterapkan guru untuk membiasakan siswa dengan sifatsifat terpuji dan baik sehingga aktifitas yang dilakukan terekam secara positif. ${ }^{4}$ Pembiasaan merupakan metode yang dianggap paling efektif dalam membentuk dan menanamkan karakter religius terhadap siswa. Pendidikan karakter religius melalui metode pembiasaan dapat dilakukan dengan cara pertama rutin yaitu pembiasaan yang dilakukan terjadwal seperti berdoa sebelum dan sesudah pelajaran, membaca surat-surat juz 'amma, membaca Asmaul Husna, shalat dhuha berjamaah, shalat dhuhur berjamaah, pemeliharaan kebersihan, ketertiban, dan lain-lain. Spontan yaitu pembiasaan yang tidak terjadwal dalam pembelajaran

4 E. Mulyasa, Manajemen Pendidikan Karakter (Jakarta: PT. Bumi Aksara, 2012), 167. dan kejadian khusus seperti pembentukan perilaku 5S, membuang sampah pada tempatnya, antri, mengatasi perbedaan pendapat, dan lain-lain. Keteladanan adalah pembiasaan dalam bentuk perilaku sehari-hari seperti berpakaian rapi, berbahasa yang baik dan lain-lain. ${ }^{5}$

Madrasah Ibtidaiyah Negeri atau MIN 2 Bandar Kidul Kota Kediri merupakan salah satu madrasah yang memperhatikan pendidikan karakter siswa baik didalam maupun diluar pembelajaran. Implementasi pembentukan karakter religius di MIN 2 Kota Kediri menitikberatkan melalui pembiasaan aktivitas keagamaan yang ada di sekolah selain kegiatan yang dilaksanakan dalam proses pembelajaran yang dilakukan sekolah baik di dalam kelas maupun di luar kelas.

Pembentukan karakter melalui pembiasaan aktifitas seharihari dimadrasah ini menjadi daya tarik tersendiri bagi masyarakat, hal ini terlihat antusiasme masyarakat sekitar dalam mempercayakan pendidikan putra-putrinya di sekolah ini. Selain itu harapan penuh orang tua dengan proses pembentukan karakter di madrasah mampu memperbaiki perilaku dan akhlak puta putri mereka.

\section{Metode}

Jenis dan pendekatan dalam penelitian ini menggunakan kualitatif deskriptif, lokasi penelitian di MIN 2 Bandar Kidul Kota Kediri. Penggalian sumber data diperoleh melalui teknik wawancara dengan

${ }^{5}$ Mulyasa, 168-69. 
kepala madrasah, waka kurikulum, waka keagamaan, wali kelas, guru PAI, perwakilan wali murid dan beberapa murid, serta hasil dari observasi langsung. Dalam memperoleh informasi yang lebih mendalam dan relevan dalam proses pengumpulan data, peneliti melalukan wawancara bebas, responden tidak menyadari sepenuhnya bahwa ia sedang di interview. Sedangkan observasi dilakukan dalam penelitian ini secara sistematisdengan menggunakan pedoman sebagai instrumen pengamatan. Untuk teknik analisis data yang diperoleh dilakukan reduksi data kemudian disajikan dalam bentuk uraian singkat, bagan dan hubungan antar kategori kemudian diambil disimpulan.

\section{Temuan dan Pembahasan Karakter Religius yang Dikembangkan di MIN Bandar Kidul}

Karakter dapat dikatakan sebagai sebagai watak atau tabiat yang dimiliki seseorang berbedabeda bukan bawaan lahir tetapi dapat dibentuk. ${ }^{6}$ Proses pendidikan karakter didasarkan pada totalitas psikologis yang mencakup keseluruhan potensi manusia baik pada ranah kognitif, afektif dan psikomotorik serta totalitas sosio cultural. ${ }^{7}$ Pendidikan karakter berkaitan dengan Moral knowing/learning to know, pada tahapan merupakan langkah awal

\footnotetext{
${ }^{6}$ Mulyasa, hlm. 3.

7 Thomas Lickona, Pendidikan Karakter (Jakarta: PT. Bumi Aksara, 2012), hlm. 25. 58
}

dalam pembentukan karakter yang orientasinya pada penguasaan pengetahuan tentang nilai-nilai. Diharapkan pada tahap ini siswa mampu membedakan nilai-nilai akhlak mulia dan akhlak tercela serta nilai-nilai universal, memahami secara logis dan rasional tentang pentingnya akhlak mulia dan bahaya akhlak tercela dalam kehidupan. Moral Feeling atau moral loving, tahapan ini dimaksudkan untuk menumbuhkan rasa cinta dan rasa butuh terhadap nilai-nilai akhlak mulia. Sasaran guru pada tahap ini adalah dimensi emosional siswa, hati, atau jiwa bukan lagi akal, rasio, dan logika. Moral doing atau moral action Merupakan puncak keberhasilan penanaman karakter, siswa mempraktikkan nilai-nilai akhlak mulia itu dalam perilakunya sehari-hari, siswa menjadi sopan, ramah, hormat, penyayang, jujur, adil, dan seterusnya. ${ }^{8}$

Pendidikan karakter religius yang dikembangkan di MIN 2 Bandar Kidul Kota Kediri merelevansikan karakter religius ke dalam tiga indikator. Indikator pertama direlevansikan pada nilai 1) ketaqwaan, 2) kebersihan, 3) kejujuran, dan 4) keikhlasan. Empat karakter ini merupakan sikap kepatuhan seorang muslim dalam melaksanakan ajaran Islam. Nilai ketaqwaan di sekolah ini tercermin dari perilaku siswa yang terbiasa melaksanakan shalat fardlu dan sunnah tepat waktu dan berjamaah seperti shalat Dhuhur dan Dhuha

${ }^{8}$ Abdul Majid dan Dian Andayani, Pendidikan Karakter Perspektif Islam (Bandung: Remaja Rosdakarya, 2011), 113.

el Bidayah: Journal of Islamic Elementary Education Volume 2, Nomor 1, March 2020 
disekolah. Selain itu juga tercermin dari perilaku siswa yang dibiasakan menggunakan pakaian syar'i dan menutup aurat dengan benar. Nilai kebersihan yang diterapkan di sekolah ini dilihat setiap depan ruangan disediakan tempat sampah dan tempat cuci tangan, kamar mandi yang ada bersih dan dilengkapi dengan fasilitas yang memadai. Penataan tanaman yang rapi juga menambah keindahan pemandangan di halaman sekolah. Siswa juga terbiasa menjaga kebersihan seperti membuang sampah pada tempatnya, jika ketahuan membuang sampah sembarang langsung ditegur oleh wali kelas atau guru yang lain untuk mengingatkan anak-anak. Nilai kejujuran dibudayakan dan ada dalam visi misi sekolah maupun dipraktikkan dalam kehidupan sehari-hari seperti dalam mengerjakan tugas dan ulangan mereka tidak mencontek. Nilai keikhlasan siswa dibiasakan dengan melakukan amal jariyah dan infaq minimal 2.000 setiap hari jum'at dan setiap pelajaran agama Islam, seperti dalam satu kelas ada yang sakit siswa mengeluarkan infaq seikhlasnya dengan tujuan membantu dan mendidik anak-anak agar saling peduli.

Indikator kedua yaitu nilai toleransi terhadap agama lain dalam kehidupan sehari-hari dengan cara hidup rukun. Walaupun agama siswa di sekolah ini semuanya muslim tetapi penerapan nilai toleransi antar umat beragama diterapkan pihak sekolah dengan mengajar tadabur ke tempat ibadah setiap agama seperti ke gereja pohsarang sebagai tempat ibadah agama Kristen.

Indikator ketiga dari karakter religius yaitu yaitu 1) kesopanan, 2) tolong-menolong, 3) kompetisi. Dengan adanya relevansinya nilainilai tersebut, maka kerukunan antar warga khususnya antar siswa dapat terwujud.

Nilai kesopanan terdapat dalam salah misi MIN 2 Bandar Kidul Kota Kediri yaitu terwujudnya budaya jujur, sopan, ikhlas, sapa, senyum dan santun atau membentuk siswa yang memilki akhlaqul karimah. Pembiasaan ini dilakukan dengan cara jika bertemu dengan guru harus mengucapkan salam dan mencium tangan. Kemudian jika bertemu dengan sesama teman mengucapkan salam dan minimal tersenyum. Dalam mewujudkan nilai kesopanan ini melalui kegiatan 5S atau Salam, salim, sapa, senyum, sopan dan santun yang sudah menjadi budaya di sekolah ini. Nilai tolong menolong tercermin dari perilaku siswa sehari-hari disekolah antara guru dengan siswa dan siswa dengan siswa yang lain. Ini terlihat ketika anak-anak diminta tolong guru ke ruang guru mereka mau melakukannya, juga termasuk dengan sesama teman saling tolong menolong dalam hal apapun seperti dalam belajar, bermain atau kegiatan menjaga kebersihan kelas. Kompetitif menjadi salah satu karakter yang dikembangkan di sekolah ini terlihat banyaknya prestasi baik akademik maupun non akademik yang diperoleh oleh siswa. Salah satu prestasi non akademik dalam bidang olahraga yaitu juara 1 Tenis Meja dan Juara 1 lomba Catur 
tingkat pelajar se-kota Kediri, selain itu juga pernah mendapat juara 2 lomba Tenis Meja tingkat provinsi Jawa Timur pada tahun 2017. Kepala madrasah sangat mendukung jika siswa mau mengikuti berbagai perlombaan dan kompetisi apa pun baik dilaksanakan di tingkat kota, kabupaten bahkan sampai dengan provinsi

Pembentukan Karakter Religius Siswa melalui Pembiasaan Aktivas Keagamaan

MIN 2 Bandar Kidul Kota Kediri merupakan madrasah yang berbasis islam yang memiliki jumlah peserta didik sangat banyak yaitu ada 836 siswa yang memiliki karakter berbeda-beda ada yang baik dan ada yang kurang baik. Perbedaan ini tidak lepas dari lingkungan tempat mereka tinggal yang berasal dari keluarga yang beragam. Sekolah sebagai tempat pembentukan karakter tidaklah mudah karena perbedaan karakter dan pemahaman siswa yang beragam. Pembentukan karakter dimulai dari pembelajaran di dalam kelas dengan memberikan materi yang mengacu pada kurikulum, silabus, dan RPP kemudian diterapkan melalui kegiatan pembiasaan. Sekolah ini mengupayakan maksimal dalam pembentukan karakter dengan berbagai pertimbangan diantaranya kepercayaan dan harapan orang tua terhadap sekolah sangat tinggi untuk memperbaiki perilaku peserta didik.

Proses pembentukan karakter yang melibatkan seluruh pihak dilingkungan sekolah dan tidak hanya wali kelas saja, termasuk 60 semua guru dan tenaga kependidikan. Strategi pembentukan karakter ini hampir sama dengan pembentukan karakter siswa di SMK PGRI 2 Kediri melalui pembiasaan yang baik dalam segala hal, seluruh pihak bertanggungjawab dalam menciptakan kondisi keagamaan disekolah, termasuk menegakkan kedisiplinan, memberikan motivasi, memahami kondisi psikologis siswa, memberikan sanksi bagi yang melanggar tata tertib dan peraturan sekolah. ${ }^{9}$

Pembentukan karakter religius yang dilakukan disekolah ini melalui kegiatan keagamaan secara rutin setiap hari dengan metode pembiasaan. Metode pembiasaan sendiri merupakan bentuk pendidikan yang pada prosesnya dilakukan secara bertahap dalam membiasakan sifat-sifat baik sebagai rutinitas, sehingga dapat melaksanakan dengan mudah dan ringan, tidak kehilangan banyak tenaga dan mudah dan tidak mengalami kesulitan melaksanakannya. ${ }^{10}$

Para pakar pendidikan juga sepakat bahwa untuk membentuk moral dan karakter religius anak dapat mempergunakan metode pembiasaan. Metode pembiasaan sangat penting diberikan dan ditanamkan kepada anak-anak usia dini khususnya usia anak sekolah dasar, dikarenakan anak dalam masa

9 M. Arif Khoiruddin dan Dina Dahniary Sholekah, "Implementasi Pendidikan Agama Islam Dalam Membentuk Karakter Religius Siswa," PEDAGOGIK : JURNAL PENDIDIKAN 6, no. 1 (1 Juli 2019): 135.

10 Armai Arief, Pengantar ilmu dan metodologi pendidikan Islam (Jakarta: Ciputat Pers, 2002), 225.

el Bidayah: Journal of Islamic Elementary Education Volume 2, Nomor 1, March 2020 
sekolah dasar itu merupakan waktu yang sangat mudah tertanam dalam diri anak ketika kita menyampaikan sebuah nasihat, pembiasaan atau ajaran agama islam. Seperti keterangan dalam sebuah hadits dari Abu Hurairah Radhiyallahu 'anhu berkata, Rasulullah Saw telah bersabda:

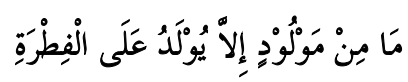

Artinya: "Tidaklah setiap anak yang lahir kecuali dilahirkan dalam keadaan fitrah"

\section{Bentuk-bentuk kegiatan} pembiasan yang dilakukan secara rutin yang dilaksanakan di MIN 2 Bandar Kidul Kota Kediri diantaranya melalui pembiasaan $5 \mathrm{~S}$ yaitu senyum, sapa, salam, sopan, dan santun yang dilaksanakan mulai dari guru menyambut siswa di pintu gerbang masuk sekolah dengan membawa alat peraga yang berisikan 5S, jika siswa lupa guru langsung memperlihatkan alat peraga tersebut dan siswa melaksanakan seperti yang ada di alat peraga tersebut. Penerapkan kebiasaan menyapa dan menghormati orang yang lebih tua, menanamkan akhlak kepada anakanak untuk tertib, sopan santun dan juga ramah kepada guru, bahkan kepada teman- temannya bertujuan agar siswa terbiasa bersikap ramah dan juga berkelakuan baik.

Pembiasaan yang kedua dengan membaca do'a sebelum dan sesudah belajar. Do'a merupakan kegiatan yang dilaksanakan setiap hari saat dimulainya proses pembelajaran. Kegiatan ini dilakukan secara rutin dengan harapan supaya peserta didik terbiasa mengawali harinya dalam melaksanakan berbagai aktifitas kegiatan apapun dengan mengharapkan ridho dari Allah SWT. Do'a bersama dilaksanakan secara bersama-sama dipimpin oleh wali kelas dengan membimbing melaksanakan pembiasaan di pagi hari. Do'a dibaca secara serentak oleh siswa, terbaca secara rapi dan indah. Dengan pembacaan do'a tersebut siswa menjadi sadar bahwa kebersamaan sangat diperlukan dalam kehidupan ini, secara bersama-sama dalam memohon kepada Allah, bersama-sama dalam mengharap ridho-Nya, dan bersamasama dalam memulai menuntut ilmu. Dalam pelaksanaan berdo'a sebelum dan sesudah pembelajaran merupakan penanaman nilai-nilai karakter religius dengan mengungkapkan puji syukur atas kehadirat-Nya serta mengharapkan karunia-Nya untuk keberkahan segala aktivitas yang dilakukan.

Pembiasaan selanjutnya kegiatan melaksanakan sholat dhuha dan sholat Dhuhur Berjamaah. Tujuan diadakan kegiatan ini untuk membiasakan siswa dalam melakukan shalat setiap harinya, shalat merupakan tiang agama yang harus dijaga dan dilakukan secara wajib, walaupun di sekolah hanya membiasakan shalat dhuha dan shalat dhuhur secara berjamaah dengan harapan khusus mereka terbiasa dalam melaksanakan shalat wajib lainnya, tujuan yang lain sebagai supaya mendekatkan diri dan mengingat kepada Allah SWT sebagai pengaplikasian rasa syukur 
terhadap nikmat yang telah diberikan kepada mereka.

Pelaksanaan sholat dhuha berjamaah dilaksanakan saat jam istirahat dan sebelum kegiatan belajar mengajar berlangsung. Pembiasaan ini dilaksanakan dan dipantau sendiri oleh guru keagamaan dan wali kelas masingmasing yang langsung terjun ke masjid untuk melihat dan mendampingi siswa yang melaksanakan sholat dhuha. Shalat dzuhur dan shalat dhuha berjamaah memiliki implikasi pada aspek spritualitas dan mentalitas bagi siswa yang sedang belajar. Metode pembiasaan sendiri peserta didik akan mulai terbiasa melaksanakannya walaupun di awal mereka merasa keberatan, akan tetapi mereka merasakan nikmatnya melaksanakan shalat dhuha dan shalat dhuha berjamaah. Tujuan diadakan shalat dhuha dan shalat dhuhur berjamaah yaitu agar membiasakan anak-anak dalam melaksanakan shalat tepat waktu baik itu shalat fardlu maupun sunah.

$$
\text { Kegiatan juz 'amma, }
$$
pembiasaan ini merupakan salah satu kegiatan rutin yang dilaksanakan setiap hari sebelum kegiatan belajar mengajar. Kegiatan dilaksanakan di kelas masingmasing dengan didamping wali kelas. Kegiatan ini bertujuan anakanak terbiasa melafadkan suratsurat di juz 30 dengan harapan dapat menggunakan dalam kegiatan sehari-hari seperti dalam shalat fardlu menggunakan surat pendek setelah al fatihah. Dalam implementasinya bukan hanya dibaca saja akan tetapi anak diwajibkan hafal dalam satu semester minimal 3 surat sesuai dengan tingkatan masing-masing, setiap bulan anak membaca satu surat dulu kalau sudah lancar tambah surat selanjutnya dan kemudian satu minggu sekali menarik hafalan mereka sesuai dengan yang dibaca setiap semester.

Membaca asmaul husna, Kegiatan ini dilaksanakan setiap hari sebelum pembelajaran. Tujuannya supaya peserta didik menghafal, mengimani, serta mengerti namanama Allah yang berjumlah 99. Dalam pelaksanaannya peserta didik sangat antusias sekali, bulan pertama mereka masih melihat dari buku panduan yang diberikan dari madrasah, bulan selanjutnya mereka sudah hafal tanpa melihat buku tersebut.

Melakukan kegiatan istighasah, pembiasan ini merupakan kegiatan rutin yang dilaksanakan setiap satu semester sekali yaitu setiap hendak melaksanakan ujian semester. Kegiatan ini bertempat di Masjid Darussalam Bandar Kidul Kota Kediri dengan tujuan mendapatkan berkah dari istighasah agar peserta didik diberi kelancaran dalam menuntut ilmu, khususnya untuk kelas enam yang akan menghadapi ujian akhir nasional diberi kelancaran dan semua bisa lulus. Seluruh peserta didik menirukan bacaan-bacaan istighasah kemudian sekitar 30 menit berlangsung, kegiatan ini ditutup dengan doa dalam keadaan hidmah, bahkan tidak sedikit peserta didik yang menghayati ketika berdoa. 
Kegiatan PHBI atau peringatan hari besar islam yang diadakan setiap setahun sekali sesuai dengan peristiwa atau kegiatan memperingati dan merayakan hari-hari besar umat Islam. Misalnya Tahun Baru Islam 1 Muharram, dan lain-lain. Acara ini dilakukan atau diperingati dalam serangkaian acara yang di susun secara terstruktur dan juga membutuhkan waktu yang lama untuk merencanakan atau memprogram acara tersebut sekaligus dalam pelaksanaannya. Kegiatan ini selalu dilakukan dalam rangka memperingati hari besar islam, seperti peringatan maulid Nabi, Isra' Mi'raj, idul fitri, idul adha. Semua kegiatan tersebut bertujuan agar siswa mampu menghayati dan mengambil ibrah dari sejarah dari peradaban islam.

Memperingati maulid nabi ini dilaksanakan setiap setahun sekali bertepatan dengan kelahiran nabi Muhammad Saw. Dalam rangka memperingati maulid Nabi Muhammad Saw pembacaan shalawat nabi bersama yang dilaksanakan di kelas masingmasing dengan didampingi wali kelas serta menceritakan kisah tentang Nabi Muhammad Saw dan peristiwa pada masa saat kelahiran nabi Muhammad Saw yang disebut dengan peristiwa tahun gajah. Kegiatan tersebut bertujuan agar siswa mampu menghayati dan mengambil ibrah dari kisah kelahiran serta peristiwa yang terjadi, dan bagaimana mulai kedatangan utusan Allah ke muka bumi ini yang bertujuan menyempurnakan akhlak manusia
Peringatan isra' mi'raj merupakan salah satu peristiwa dimana perintah dari Allah Swt untuk melaksanakan shalat 5 waktu dalam sehari. Sebagaimana dengan peringatan maulid Nabi Muhammad Saw, di MIN 2 Bandar Kidul kegiatan memperingati isra' mi'raj merupakan kegiatan keagamaan yang rutin dilaksanakan satu tahun sekali. Kegiatan peringatan isra' mi'raj menurut guru-guru di MIN 2 Bandar Kidul Kota Kediri merupakan salah satu kegiatan yang bernilai positif sebagai media penyampaian tentang sejarah perintah shalat dari Allah Swt melalui Nabi Muhammad Saw dari peristiwa tersebut.

Kegiatan ini bertujuan untuk melatih mental kebersamaan dan meningkatkan keimanan peserta didik supaya mereka menjadi siswasiswi yang memiliki rasa kebersamaan dengan baik. Kemudian Kegiatan pondok ramadhan atau pesantren kilat adalah salah satu kegiatan pelatihan dan pendidikan serta pengembangan sumber daya manusia yang dilakukan secara sistematik dikalangan anak-anak. Kegiatan ini bertujuan untuk memperdalam ibadah dan pengetahuan ke-islaman pada diri pesera didik. Kegiatan Pondok Ramadhan atau Pesantren Kilat, ini bertujuan untuk lebih mendekatkan anak-anak dengan bulan ramadhan, kemudian dengan memberikan tambahan pembelajaran seputar puasa, zakat fitrah, hari raya idhul fitri dan lain sebagainya. Biasanya mahasiswa IAI-Tribakti ikut berbagi ilmu dan pengalaman. Selain itu juga 
mengadakan pembiasaan tadarus AlQur'an di kelas masing-masing, serta membagikan ta'jil setiap sore bersama guru dan wali murid dan peserta didik setiap menjelang berbuka puasa.

Seluruh kegiatan pembiasaan yang dilakukan di MIN 2 Bandar kidul merupakan implementasi dari metode yang digunakan untuk membentuk karakter religius siswa sebagaimana dijelaskan gunawan dengan melakukan pembiasaanpembiasaan kepada peserta didik yang tujuannya agar terbiasa melakukan perilaku terpuji, disiplin, giat belajar, kerja keras, ikhlas, jujur dan bertanggung jawab terhadap segala tugas yang dilakukan. ${ }^{11}$

\section{Kesimpulan}

Madrasah Ibtida'iyah Negeri 2 Bandar Kidul mengembangkan beberapa karakter religius yakni berupa nilai ketaqwaan, keikhlasan, kejujuran, kesopanan, tolongmenolong, kebersihan, cinta rosul dan kompetitif. Pembentukan karakter religius siswa melalui pembiasaan aktivitas keagamaan yang dilaksanakan di MIN 2 Bandar Kidul Kota Kediri merupakan salah satu upaya yang dilaksanakan madrasah dalam membentuk karakter religius siswa diantaranya adalah doa bersama sebelum dan sesudah pembelajaran, pelaksanaan shalat dhuha dan dhuhur berjamaah, pembacaan juz 'amma, asmaul husna, istighasah, infaq, pembiasaan 5S (salam, senyum, sapa, sopan, santun), kegiatan ekstrakulikuler keagamaan seperti rebana, BTQ dan lain-lain, serta kegiatan Peringatan Hari Besar Islam (PHBI) yang terdiri dari isra' mi'raj, maulid Nabi Muhammad Saw, dan Idhul adha. Karakter religius yang terbentuk dari adanya pembiasaan aktivitas keagamaan diantaranya adalah ketaqwaan, keikhlasan, kejujuran, kesopanan, tolong-menolong, toleransi, kompetitif, kebersihan, dan cinta rosul.

\section{Daftar Pustaka}

Arief, Armai. Pengantar ilmu dan metodologi pendidikan Islam. Jakarta: Ciputat Pers, 2002.

Gunawan, Heri. Pendidikan Karakter Konsep dan Implementasi. Bandung: Alfabeta, 2012.

Kesuma, Dharma. Pendidikan Karakter Kajian Teori dan Praktik di Sekolah. Bandung: PT. Remaja Rosdakarya, 2011.

Khoiruddin, M. Arif. "Perkembangan Anak Ditinjau Dari Kemampuan Sosial Emosional." Jurnal Pemikiran Keislaman 29, no. 2 (24 Desember 2018): 425 438425 438.

https://doi.org/10.33367/tribak ti.v29i2.624.

Khoiruddin, M. Arif, dan Dina Dahniary Sholekah. "Implementasi Pendidikan Agama Islam Dalam Membentuk Karakter Religius Siswa." PEDAGOGIK: JURNAL

11 Heri Gunawan, Pendidikan Karakter Konsep dan Implementasi (Bandung: Alfabeta, 2012), 94. 
PENDIDIKAN 6, no. 1 (1 Juli 2019): 123-44.

Lickona, Thomas. Pendidikan Karakter. Jakarta: PT. Bumi Aksara, 2012.

Majid, Abdul, dan Dian Andayani. Pendidikan Karakter Perspektif Islam. Bandung: Remaja Rosdakarya, 2011.

Mulyasa, E. Manajemen Pendidikan Karakter. Jakarta: PT. Bumi Aksara, 2012.

Samani, Muchlas, dan Haryanto. Konsep dan Model Pendidikan Karakter. Bandung: PT. Rosdakarya, 2013. 